\title{
Options for Prevention of HIV Transmission from Mother to Child, with a Focus on Developing Countries
}

\author{
Louise Kuhn and Ingrid Peterson
}

Gertrude H. Sergievsky Center, College of Physicians \& Surgeons, Columbia University, and Department of Epidemiology, Joseph L. Mailman School of Public Health, New York, USA

\section{Contents}

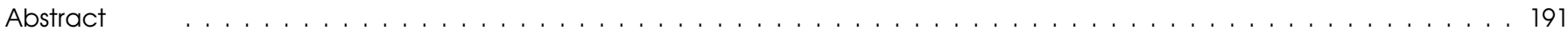

1. Timing and Mechanisms of Mother-to-Child HIV Transmission . . . . . . . . . . . . . . . . . . . . . . . . . . . . 192

1.1 In Utero and Intrapartum Transmission . . . . . . . . . . . . . . . . . . . . . . . . . . . . . . . 192

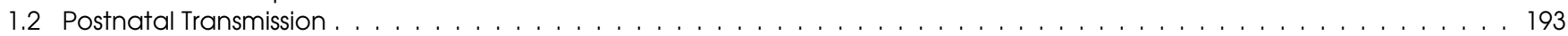

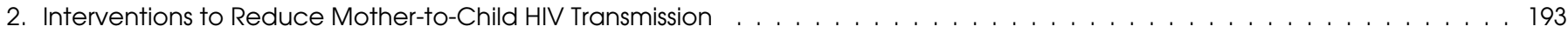

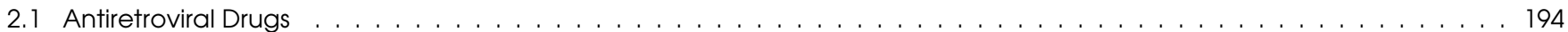

2.2 Obstetric Interventions: Cesarean Sections and Vaginal Lavage . . . . . . . . . . . . . . . . . . . . . . . . . . 197

2.3 Vitamin A and Other Micronutrients . . . . . . . . . . . . . . . . . . . . . . . . . . . . . . . . . . . 198

2.4 Exclusive Breast Feeding and Early Cessation of Breast Feeding . . . . . . . . . . . . . . . . . . . . . . . . 198

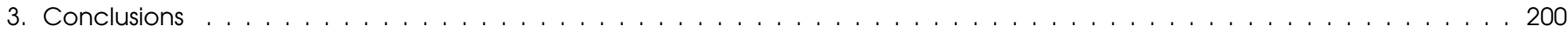

Abstract

Use of antiretroviral drugs among HIV-infected pregnant women in many developed countries has significantly reduced rates of mother-to-child HIV transmission, demonstrating that this route of transmission is amenable to intervention. Prevention of transmission in developing countries has proved to be more difficult, although recent advances in short-course antiretroviral drug interventions have made it an immediate possibility, rather than a distant hope as it was seen to be in the recent past. Non-antiretroviral drug interventions, including washing of the birth canal with antiseptic solution and micronutrient supplementation, have not been found to be effective at interrupting mother-to-child HIV transmission, but may have other benefits for maternal and child health. An important issue for developing countries is prevention of postnatal HIV transmission through breast feeding. In most developing countries, formula feeding is not a reasonable option, given the higher rates of mortality from diarrheal and respiratory disease associated with avoidance of all breast feeding. A promising new line of research has recently been broached with the findings from a study in South Africa, which demonstrated that exclusive breast feeding is associated with a significant reduction in postnatal transmission of HIV.

Mother-to-child transmission of HIV is an important aspect of the AIDS pandemic and has rightly been the focus of much preventive research. In the absence of interventions, an estimated 20 to $30 \%$ of infants born to HIV-infected mothers will also become infected. ${ }^{[1]}$ In the US and Europe, widespread use of antiretroviral drugs among HIV-infected pregnant women has reduced rates of mother-to-child HIV transmission to as low as $2 \%$, demonstrating that this route of transmission is amenable to intervention. ${ }^{[2]}$ Much recent research, therefore, has focused on the reduction of mother-to-child HIV transmission in developing countries, where perinatal HIV infection contributes significantly to infant mortality. Data from southern and eastern Africa, for example, suggest infant and child mortality is now almost twothirds higher than it would have been in the absence of HIV/ AIDS. ${ }^{[3]}$

Several factors amplify mother-to-child HIV transmission in developing countries. Women in developing countries have little access to HIV testing and treatment or prenatal care, which were necessary elements involved in the substantial reduction of mother-to-child transmission in developed countries. HIV sero- 
prevalence among women of childbearing age (15 to 49 years) is significantly higher in many developing countries than in the US and Europe. In sub-Saharan Africa, it is estimated to be about 8\% overall, and as high as $36 \%$ in some areas, compared with $0.25 \%$ in the US. ${ }^{[4]}$ Furthermore, seroprevalence data indicate that HIV infection is increasing most in women in their twenties, the population segment with the highest fertility. Finally, breast feeding is nearly universal in almost all developing countries. While it provides many health benefits, it also entails potential exposure of infants to HIV.

The factors listed above should not be interpreted as immutable or unsurpassable barriers to the control of mother-to-child transmission of HIV in developing countries. Recent advances in short-course antiretroviral drug interventions have made prevention an immediate possibility, rather than a distant hope as it was seen to be in the recent past. Nor, for that matter, should it be assumed that control of perinatal HIV infection is uniformly satisfactory in developed countries. Surveillance data in the US, for example, show that mother-to-child transmission is significantly higher among young minority women in inner-city areas. ${ }^{[2]}$ These diverse situations underscore the need for creative, forward-looking and situationally relevant epidemiologic research into the prevention of mother-to-child transmission.

From this perspective, this paper provides an overview of the current avenues of epidemiologic research related to the prevention of mother-to-child HIV transmission, with an emphasis on developing countries. Issues regarding the timing and biological mechanisms underlying mother-to-child transmission are briefly reviewed, followed by a discussion of specific interventions.

\section{Timing and Mechanisms of Mother-to-Child HIV Transmission}

The timing of mother-to-child HIV transmission has important implications for the development of interventions aimed at disrupting transmission occurring in utero, intrapartum and postnatally. Diagnostic, clinical and epidemiologic data have provided the basis of current knowledge about the timing and specific etiological mechanisms of transmission. A brief review of these data will establish a framework for the discussion of preventive interventions, which follows later in the paper.

\subsection{In Utero and Intrapartum Transmission}

The timing of mother-to-child HIV transmission has been the subject of some controversy. In particular, it has been difficult to determine the relative contributions of in utero and intrapartum transmission to the overall rate of transmission. ${ }^{[5]}$ Clinical signs of HIV disease do not clearly distinguish intrauterine from intrapartum transmission. In utero HIV infection does not appear to have unique clinical manifestations, clinical signs of HIV in neonates are rare, and there is a wide variation in the natural history of HIV-associated disease among infected infants, with some showing rapid progress of disease in the first year of life and others surviving into childhood and adolescence. ${ }^{[6]}$

The best available data on the timing of transmission have come from virologic methods of diagnosing HIV infection, specifically viral culture, and amplification of HIV DNA by polymerase chain reaction (PCR). These tests detect the presence of circulating virus in the blood and, therefore, are not influenced by passive transfer of maternal antibodies, which limits the use of standard antibody assays in infants. Viral culture and PCR when used in neonates within a day or two of birth have sensitivities of only about $30 \% .{ }^{[7-10]}$ It has been inferred from these results that in non-breast-feeding infants who have no detectable virus at birth but who are later determined to be HIV-infected, the lack of detectable virus near birth is indicative of recent infection (i.e. very late in utero, or during birth). Given this, in utero infection is typically defined by the detection of virus in the infant's peripheral blood through virologic methods within 48 hours of birth, while intrapartum infection is defined by a negative finding within 48 hours of birth with positive findings occurring only later within 1 week to 90 days of birth. ${ }^{[11]}$ This classification system is clearly imperfect, and factors other than the timing of transmission may influence whether early diagnostic tests are positive or negative. For example, among infants infected in utero, HIV may remain sequestered in noncirculating tissues before activation of the infant's immune system. In this instance, HIV will not be found circulating in the infant's peripheral blood within 48 hours of birth.

Other epidemiologic data, however, tend to support the notion that most mother-to-child transmission among non-breast-fed infants occurs during birth. One line of evidence to support the importance of intrapartum transmission comes from findings that in HIV-exposed vaginally delivered twins, first-born twins have significantly higher rates of HIV infection than second-born twins. ${ }^{[12,13]}$ Higher rates of infection observed among HIV-exposed infants after prolonged rupture of membranes prior to delivery ${ }^{[14]}$ and lower rates of infection observed among those delivered by elective cesarean section ${ }^{[15]}$ also support the importance of this route of transmission. Intrapartum HIV transmission may occur in labor through maternal-fetal microtransfusions of blood and through direct mucosal contact of the infant with infected fluids and blood in the birth canal. ${ }^{[16]}$ 
The presumed rarity of in utero HIV transmission conforms to what is known about the effectiveness of the placental barrier in preventing maternal pathogens from reaching fetal circulation. In utero infection is thought to occur either through breaks in the placental barrier or through direct infection of the cells in the trophoblastic layer of the placenta. Evidence of the latter comes from identification of HIV in trophoblasts of some HIV-exposed placentas $^{[17,18]}$ and the observation that trophoblasts can be infected with HIV in vitro. ${ }^{[19,20]}$ Other researchers, however, have found placental infection to be rare, ${ }^{[21]}$ leading to the conclusion that in utero transmission occurs primarily through breaks in the placental barrier. Despite the likely preponderance of HIV transmission near birth, studies of electively aborted fetuses of HIVinfected women suggest that early in utero HIV infection can occur. $^{[22-25]}$

\subsection{Postnatal Transmission}

It is well established that HIV can be transmitted during the postnatal period through breast feeding, although the frequency of transmission via this route is not accurately quantified. The widely quoted estimate of $14 \%$ [95\% confidence interval (CI) 7 to $22 \%$ ] as the excess risk of HIV infection associated with postnatal exposure to breast milk from women with prevalent HIV infection is based on a meta-analysis with serious methodological flaws. ${ }^{[26]}$ In the meta-analysis, the excess risk was calculated by subtracting the overall transmission rate observed among HIVinfected women who had never breast fed their infants from the rate among women who had breast fed; however, none of the individual studies included in the meta-analysis had recruited substantial numbers of ever and never breast-fed infants: in studies conducted in Africa, most infants were breast fed; in studies conducted in the US and Europe, most were not. Furthermore, other factors associated with the decision to breast feed were not taken into account. Despite the methodologic limitations of the meta-analysis, its estimate of the excess risk associated with breast feeding has largely been supported. Notably, a randomized clinical trial conducted in Nairobi, Kenya, generated a similar estimate for the excess risk of postnatal transmission of $16 \%$ (95\% CI 7 to $26 \%$ ). ${ }^{[27]}$

Breast feeding cannot simply be considered as a homogeneous, all-or-nothing exposure. Some epidemiologic data suggest that the risk of postnatal HIV-1 infection is greatest early on. In the Nairobi trial, $63 \%$ of the excess risk associated with breast feeding had occurred in infants by age 6 weeks. ${ }^{[27]}$ A cohort study conducted in Malawi of infants breast fed by their HIV-infected mothers also observed a trend for decreasing incidence of postnatally acquired HIV infection as children aged. ${ }^{[28]}$ An important question requiring further study is whether the observed predominance of early postnatal transmission is due primarily to agespecific risk mechanisms (such as infant immune immaturity), variations in breast milk infectivity over time, or other factors. ${ }^{29]}$ Despite the apparent declining risk over time, several studies support the notion that breast feeding poses a detectable risk of HIV infection transmission throughout the duration of breast feeding. ${ }^{[30-34]}$ In almost all the observational cohort studies that investigated this, new infections continued to be observed while breast feeding continued, although the risk of such 'late postnatal' infection may have been as low as 3 per 100 child-years of breastfeeding follow-up. ${ }^{[35]}$

Largely overlooked in research into postnatal HIV transmission has been the important distinction made by nutritionists between exclusive and partial or predominant breast feeding. Exclusive breast feeding is defined as breast feeding in the complete absence of all other fluids and solids and is recommended for up to 6 months of age, during which time breast milk alone can satisfy all the infant's nutritional and fluid needs. ${ }^{[36]}$ Though rarely practiced, exclusive breast feeding has long been known to be superior to partial and predominant breast feeding as a way of reducing non-HIV-related infant morbidity and mortality in the first 6 months of life. ${ }^{[37-39]} \mathrm{A}$ recent observational study conducted in Durban, South Africa, observed no increased risk in infants being exclusively breast fed compared with never breast-fed infants. Postnatal transmission rates at comparable ages were significantly higher among predominantly and partially breast-fed infants than among their exclusively breast-fed counterparts. ${ }^{[40]}$ While these findings require confirmation, they highlight the importance of clarifying not only the duration, but also the quality of breast feeding when discussing rates of postnatal HIV transmission.

Another aspect of postnatal HIV transmission is highlighted in findings that mothers infected postnatally with HIV are at higher risk of transmitting the virus to their infants, probably because of peak viremia associated with initial infection. ${ }^{[41]}$ Approximately $30 \%$ of women with primary HIV infection while breast feeding are thought to transmit HIV to their infants via breast milk. ${ }^{[26]}$ In areas where the incidence of adult HIV infection is high, this issue has important public health implications. All in all, these data underscore the importance of breast feeding as a potential source of HIV infection in infants.

\section{Interventions to Reduce Mother-to-Child HIV Transmission}

Having reviewed the salient aspects of the timing and mechanisms of mother-to-child HIV transmission, we now turn to an 
examination of the major areas of research related to interrupting transmission, including antiretroviral drug prophylaxis, preventive cesarean section and vaginal lavage, prenatal use of vitamins, and exclusive breast feeding. Research into these interventions has led to new questions about hypothesized mechanisms of transmission and has brought forth debates about the ethics, feasibility and standards relating to public health policy and research in developing countries. The following discussion outlines the central findings of such research trajectories, while highlighting areas that will be of concern in future research.

\subsection{Antiretroviral Drugs}

A major breakthrough in the study of prevention of motherto-child HIV transmission was provided in 1994 by the Pediatric AIDS Clinical Trial Group (PACTG) protocol number 076 clinical trial of the three-part prophylactic regimen of zidovudine (ZDV). ${ }^{[42]}$ Carried out in a ZDV-naïve, relatively asymptomatic, and non-breast-feeding population in the US and France, the PACTG 076 clinical trial showed a $67.5 \%$ reduction in motherto-child HIV transmission in treated individuals compared with controls, thus demonstrating the principle that antiretroviral drug prophylaxis substantially reduces the risk of mother-to-child HIV transmission. Subsequent observational studies suggested that the PACTG 076 regimen was effective in individuals previously treated with ZDV as well as in those with more advanced HIV-1 disease. ${ }^{[43-47]}$ Furthermore, an observational study of pregnant women in the US found that even abbreviated periods of ZDV use were associated with some reduction of HIV transmission. ${ }^{[48]}$ Data from various study populations suggest that the overall effectiveness of the PACTG 076 regimen in clinical practice is exceptionally good. Some studies of HIV-infected women in the US have reported transmission rates as low as 3 to $6 \%,{ }^{[2]}$ but whether these low rates are solely attributable to implementation of the PACTG 076 prophylactic protocol or to more widespread treatment of HIV-infected women with highly active combinations of antiretroviral drugs is unclear.

Since rapidly becoming the standard of care in the US in 1994, uptake of the PACTG 076 regimen in clinical practice has been remarkable, and has been largely credited with the observed 67\% decline in perinatal AIDS in the US from 1992 to 1997.[49-51] Observational studies and surveillance data have shown that the percentage of HIV-infected pregnant women identified in the prenatal period who are offered and given ZDV has increased substantially from just $7 \%$ in 1993 to $91 \%$ in $1997 ;{ }^{[50]}$ however, while the PACTG 076 regimen has had a substantial effect on motherto-child transmission of HIV in the US population overall, access to the intervention is significantly lower in population subgroups such as adolescents, socioeconomically disadvantaged groups, and illicit drug users. ${ }^{[2,52]} \mathrm{A}$ major barrier to ZDV prophylaxis in these groups is the persistence of inadequate, late or nonexistent prenatal care, as well as low rates of early identification of maternal HIV status. ${ }^{[2]}$

Despite its public health impact in the US and Europe, the PACTG 076 regimen was never seriously considered as an option for developing countries, largely because of drug costs and the inadequacy of health infrastructure in many countries. The urgency of developing and testing more appropriate short-course antiretroviral drug regimens for use in developing countries with high maternal HIV seroprevalence was acutely felt after the success of PACTG 076. To this end, several placebo-controlled clinical trials were carried out in Africa and Asia to determine the efficacy of various short-course antiretroviral regimens. These trials were sharply criticized for using placebo controls when an existing therapy, namely the PACTG 076 regimen, was known to be efficacious. Further discussion about this important issue can be found elsewhere. ${ }^{[53]}$

The efficacy of short-course regimens can be most directly compared with that of the PACTG 076 protocol, either in nonbreast-feeding or breast-feeding populations, by considering the regimens' short-term effects on HIV transmission attributable to intrauterine and intrapartum routes only. Overall, results of these clinical trials indicate significant reductions ( 34 to $50 \%)$ in intrauterine and intrapartum HIV transmission associated with shortcourse antiretroviral drug interventions (table I). ${ }^{[54-58]}$ Although possibly less efficacious than the PACTG 076 regimen, these regimens offer potentially feasible options for settings where the HIV pandemic predominates. In addition, studies that examined the use of short-course antiretroviral drug regimens over the longer term in breast-feeding populations demonstrate that although breast feeding reduces the efficacy of antiretroviral drug prophylaxis, there remains significant benefit in the use of these therapies in nursing populations (figure 1). ${ }^{[59]}$ Studies are under way to test whether continued use of antiretroviral drugs during the postnatal period can reduce breast feeding-associated transmission.

Areas of continued interest to researchers are determination of the following: the part of an antiretroviral regimen most essential to preventing mother-to-child HIV transmission; and the duration of treatment needed for efficacy. Data from the clinical trials reviewed above provide some evidence with regard to these questions. Firstly, the observed efficacy of short-course regimens, which are started in the late prenatal period or intrapartum, suggests that most of the preventive effect of the PACTG 076 regimen is not due to initiation early in gestation; however, data from 
Table I. Randomized clinical trials to evaluate the efficacy of antiretroviral drugs in reducing mother-to-child transmission of HIV in non-breast-feeding populations and over the short term in breast-feeding populations

\begin{tabular}{|c|c|c|c|c|}
\hline Study, site, date & $\begin{array}{l}\text { Sample } \\
\text { size }\end{array}$ & Intervention & $\begin{array}{l}\text { Outcome [efficacy }^{a} \text { or transmission } \\
(95 \% \mathrm{Cl}) \text { ] }\end{array}$ & Breast fed \\
\hline $\begin{array}{l}\text { PACTG 076, }{ }^{[42]} \text { United } \\
\text { States, } 1994\end{array}$ & 363 & $\begin{array}{l}\text { Mother: } 100 \mathrm{mg} \text { ZDV } 5 \text { times daily upon } \geq 14 \mathrm{wk} \\
\text { gestation, intravenous ZDV at delivery. } \\
\text { Neonate: ZDV for } 6 \mathrm{wk}\end{array}$ & $\begin{array}{l}\text { Efficacy at } 18 \mathrm{mo} \text { compared with placebo: } \\
67.5(40.7,82.1) p<0.0001\end{array}$ & No \\
\hline \multirow[t]{3}{*}{$\begin{array}{l}\text { PETRA, }{ }^{[57]} \text { South Africa, } \\
\text { Tanzania, Uganda, } 1997\end{array}$} & 1326 & $\begin{array}{l}\text { Intensive mother: ZDV-3TC from } 36 \mathrm{wk} \text {, during } \\
\text { labor, to } 1 \mathrm{wk} \text { past delivery. } \\
\text { Neonate: ZDV-3TC for } 1 \mathrm{wk}\end{array}$ & $\begin{array}{l}\text { Efficacy at } 6 \text { wk compared with placebo } \\
\text { (no Cl available): intensive } 50 \text {; } \\
\text { labor/postpartum } 37 \text {; labor only } 0\end{array}$ & Yes \\
\hline & & $\begin{array}{l}\text { Labor/postpartum mother: ZDV and 3TC from } \\
\text { labor to } 1 \text { wk past delivery. } \\
\text { Neonate: no treatment }\end{array}$ & & \\
\hline & & $\begin{array}{l}\text { Labor-only mother: ZDV and 3TC at onset of } \\
\text { labor. } \\
\text { Neonate: no treatment }\end{array}$ & & \\
\hline CDC, ${ }^{[56]}$ Thailand, 1999 & 393 & $\begin{array}{l}\text { Mother: } 300 \mathrm{mg} \text { ZDV twice daily from } 36 \mathrm{wk} \\
\text { gestation, oral dose at onset of labor, then } \\
\text { every } 3 \mathrm{~h} . \\
\text { Neonate: no treatment }\end{array}$ & $\begin{array}{l}\text { Efficacy at } 6 \text { mo compared with placebo: } \\
50.1(15.4,70.6) p=0.006\end{array}$ & No \\
\hline CDC, ${ }^{[54]}$ Côte d'Ivoire, 1999 & 280 & $\begin{array}{l}\text { Mother: } 300 \mathrm{mg} \text { ZDV twice daily from } 36 \mathrm{wk} \\
\text { gestation, oral dose at onset of labor, then } \\
\text { every } 3 \mathrm{~h} \text {. } \\
\text { Neonate: no treatment }\end{array}$ & $\begin{array}{l}\text { Efficacy at } 4 \text { wk compared with placebo: } \\
44(-1.0,69.0) p=0.05\end{array}$ & Yes \\
\hline $\begin{array}{l}\text { Ditrame }{ }^{[55]} \text { Côte d'lvoire, } \\
\text { Burkina Faso, } 1999\end{array}$ & 431 & $\begin{array}{l}\text { Mother: } 300 \mathrm{mg} \text { ZDV twice daily from } 36 \mathrm{wk} \\
\text { gestation, oral dose at onset of labor, then } \\
\text { every } 3 \mathrm{~h}, 1 \mathrm{wk} \text { of ZDV postpartum. } \\
\text { Neonate: no treatment }\end{array}$ & $\begin{array}{l}\text { Efficacy at } 45 \text { days compared with } \\
\text { placebo: } 34(0.0,66.0)\end{array}$ & Yes \\
\hline HIVNET, ${ }^{[58]}$ Uganda, 1999 & 609 & $\begin{array}{l}\text { Nevirapine mother: } 200 \mathrm{mg} \text { at onset of labor. } \\
\text { Neonate: single dose } 2 \mathrm{mg} / \mathrm{kg} \text { within } 72 \mathrm{~h} \text { of birth } \\
\text { ZDV mother: } 600 \mathrm{mg} \text { orally at onset of labor, } \\
\text { and } 300 \mathrm{mg} \text { every } 3 \text { hours. } \\
\text { Neonate: } 1 \text { week of ZDV }\end{array}$ & $\begin{array}{l}\text { Efficacy at 6-8wk nevirapine vs ZDV: } 44 \\
(24.0,64.0) p<0.0001\end{array}$ & Yes \\
\hline \multirow[t]{4}{*}{$\begin{array}{l}\text { Lallemant et al., }{ }^{[60]} \text { Thailand, } \\
2000\end{array}$} & 1409 & $\begin{array}{l}\text { Short-short (s-s) mother. ZDV from } 35 \text { wk gestation } \\
\text { through delivery. } \\
\text { Neonate: } 3 \text { days of ZDV }\end{array}$ & $\begin{array}{l}\text { Actual HIV transmission rate at } 6 \text { mo s-s: } \\
10.5(6.4,14.4) p=0.004 \text { vs } \mathrm{I}-\mathrm{I}\end{array}$ & No \\
\hline & & $\begin{array}{l}\text { Short-long (s-I) mother: ZDV from } 35 \text { wk gestation } \\
\text { through delivery. } \\
\text { Neonate: } 6 \text { wk of ZDV }\end{array}$ & s-I: $8.6(5.6,11.6)$ NS vs I-I & \\
\hline & & $\begin{array}{l}\text { Long-short (I-s) mother: ZDV from } 28 \text { wk gestation } \\
\text { through delivery. } \\
\text { Neonate: } 3 \text { days of ZDV }\end{array}$ & I-s: $4.7(2.4,7.0) \mathrm{NS}$ vs I-I & \\
\hline & & $\begin{array}{l}\text { Long-long (I-I) mother: ZDV from } 28 w k \text { gestation } \\
\text { through delivery. } \\
\text { Neonate: } 6 \text { wk of ZDV }\end{array}$ & I-1: $6.5(4.1,8.9)$ & \\
\hline
\end{tabular}

a Efficacy is defined as the percentage reduction in HIV transmission.

b Transmission is defined as the percentage infected.

3TC = lamivudine; $\mathbf{C l}=$ confidence interval; $\mathbf{m o}=$ months; $\mathbf{N S}=$ not significant; $\mathbf{w k}=$ weeks; $\mathbf{Z D V}=$ zidovudine.

an equivalence trial comparing various short-course ZDV regimens with a regimen similar to the full-length PACTG 076 regimen show that starting prophylaxis earlier (i.e. 28 weeks versus 35 weeks) increases effectiveness of the regimen. ${ }^{[60]}$ Interestingly, lengthening the postnatal component from 3 days to 6 weeks could also increase effectiveness of the regimen and could counteract the reduced effectiveness of starting the regimen relatively late during the postnatal period. Specifically, the study showed 


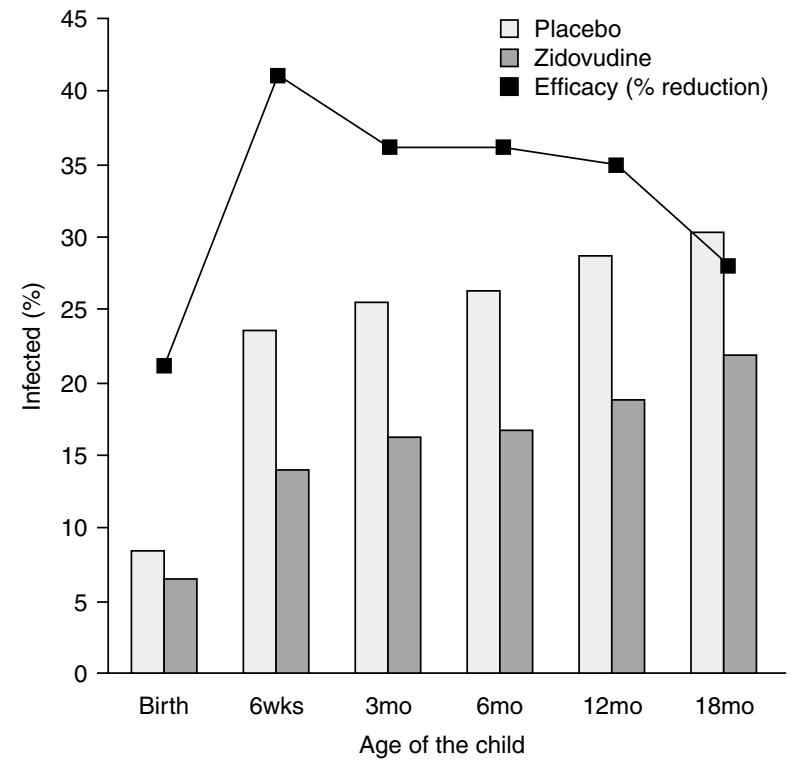

Fig. 1. Longer-term efficacy of short-course zidovudine to prevent mother-to-child HIV transmission. ${ }^{[59]} \mathbf{m o}=$ months; $\mathbf{w k s}=$ weeks.

no statistical difference in HIV incidence in infants exposed to ZDV from 35 weeks' gestation to 6 weeks postnatally compared with infants who received essentially the full-length PACTG 076 regimen. ${ }^{[60]}$ The labor-only use of antiretroviral drugs appears to be ineffective for reducing transmission. ${ }^{[57]}$

Another area of active research is the role of maternal viral load in accounting for the efficacy of antiretroviral drug prophylaxis. Since maternal viral load, as measured by HIV RNA quantities in maternal plasma, is one of the strongest correlates of motherto-child HIV transmission, ${ }^{[61-63]}$ it was assumed that the benefits of antiretroviral drug prophylaxis would be explained by viral reductions; however, this was not borne out by analysis of data from the PACTG 076 trial. After initiation of ZDV, small reductions were observed in HIV RNA copy numbers in maternal plasma by the time of delivery, but these decreases could account for only a small fraction of the reduction observed in HIV transmission. ${ }^{64]}$ Other mechanisms are thus likely to account for the benefit of antiretroviral drug interventions. The observed effectiveness of postexposure prophylaxis in healthcare workers, ${ }^{[65]}$ and some nonclinical trial data attesting to the same in infants, ${ }^{[48]}$ point to the existence of other mechanisms through which ZDV may act to prevent transmission. Further research is needed to elucidate how ZDV prophylaxis may affect these other factors and thus reduce the risk of mother-to-child HIV transmission. Nevertheless, reduction of maternal viral load may be an effective intervention. Evidence to date suggests that women treated with effective drug cocktails potent enough to suppress viremia during pregnancy have very low rates of HIV transmission. ${ }^{[66,67]}$

An important topic to be considered in future research into antiretroviral drugs is the potential for long-term adverse effects of antiretroviral drug prophylaxis in mothers and children. Thus far, analysis of PACTG 076 data has shown no difference in immunologic function, cognitive development, growth, or mortality in the first years of life among infants whose mothers used ZDV in pregnancy compared with infants whose mothers did not. ${ }^{[68]}$ Data about short-course ZDV use in Thailand also showed no significant adverse events within 18 months of follow-up. ${ }^{[69]} \mathrm{Al}-$ though these findings are encouraging, rarer and longer-term adverse outcomes require further investigation. Indications of the potential for rare adverse outcomes associated with ZDV prophylaxis come from a registry of clinical and observational data of mother-to-child HIV transmission in France, which reveals an abnormally high, though still rare, occurrence of mitochondrial abnormalities in infants exposed to ZDV. ${ }^{[70,71]}$ It has not been possible to replicate these observations in the US ${ }^{[72]}$ Further evidence of possible ZDV toxicity has been shown in animal studies, as well as in findings that exposed women and their infants had ZDV incorporated in their DNA, suggesting the tumorigenic potential of ZDV in humans. ${ }^{[73]}$ At present, however, it is clear that the health benefits of antiretroviral drug prophylaxis in HIVinfected pregnant women far outweigh the theoretical risks, and women should continue to be offered these therapies while being fully informed of the issues of possible toxicity.

Perhaps of more immediate concern than toxicity is the obstacle that drug resistance may pose to the effectiveness of ZDV prophylactic monotherapy in preventing transmission. Studies have demonstrated that, although rare, development of ZDVresistant strains can occur among women taking ZDV during pregnancy $;{ }^{[74,75]}$ however, this is more common among women with prior exposure to ZDV or with more advanced clinical disease. ${ }^{[76]}$ Viral resistance to ZDV in the presence of ZDV prophylaxis appears to increase the risk of mother-to-child HIV transmission in some, ${ }^{[77]}$ but not all reports. ${ }^{[78]}$ In the report that observed an increase in HIV transmission associated with resistance to ZDV, resistance was associated with a higher viral load but predicted HIV transmission independent of viral load. ${ }^{[77]}$ It is not clear what accounts for the contradictory findings, and there is evidence to suggest that wild strains are more efficiently transmitted than mutant strains, independent of their abundance in maternal plasma. ${ }^{[74]}$ Resistance to nevirapine is common, even after the single dose used for prophylaxis. ${ }^{[79]}$ The clinical significance of resistance to nevirapine in subsequent pregnancies needs to be investigated, and ongoing monitoring of viral sensi- 
tivity to the drugs most commonly used for prophylaxis will be necessary in the long term as these drugs become more widely used in developing countries.

The critical research question now for prevention of motherto-child HIV transmission in developing countries is how to implement programs to make antiretroviral drug interventions available to the many HIV-infected pregnant women who need them. Moving from clinical trial results, which demonstrated unambiguous benefit for these relatively simple and inexpensive (in terms of drug costs) interventions, to public programs has proved especially difficult. Obstacles have emerged from several sources within international agencies, private enterprise and national governments, and individual resistance to HIV testing and interventions is widespread. Continued support is needed for researchers and service providers in their efforts to understand situation-specific impediments to implementation and to find creative ways to overcome them.

\subsection{Obstetric Interventions: Cesarean Sections and Vaginal Lavage}

Antiretroviral drugs are likely to remain the cornerstone of interventions to interrupt mother-to-child HIV transmission and are the interventions most strongly supported by research; however, other interventions, particularly those focused on the intra- partum period, may be useful to supplement drug interventions or in special circumstances in which antiretroviral drugs cannot be, or have not been, used.

One such obstetric intervention is elective cesarean delivery. The idea that cesarean delivery may be effective to reduce HIV transmission hinges, in part, on the concept that most mother-tochild HIV transmission probably occurs during labor and delivery. Initial studies, many of which predated the antiretroviral drug era, were inconsistent and ambiguous regarding whether or not mode of delivery was associated with transmission. ${ }^{[80,81]}$ In part, the lack of clarity was due to small sample sizes, but primarily to a failure to distinguish correctly between elective and emergency procedures. When elective procedures were rigorously defined, based on their use prior to membrane rupture, cesarean delivery reduced the risk of infant HIV infection by more than $50 \%$, after adjusting for several potential confounders including maternal disease stage, antiretroviral drug use, and birth weight. ${ }^{[15]} \mathrm{A}$ small, multisite clinical trial in Europe confirmed the benefit of elective cesarean delivery to reduce HIV transmission, reporting an $80 \%$ lower risk of HIV infection with cesarean compared with vaginal delivery (table II). ${ }^{[82]}$ Of note, the benefits of elective cesarean delivery and ZDV monotherapy appear to be additive, with reductions in mother-to-child HIV transmission observed to

Table II. Randomized clinical trials to evaluate the efficacy of other interventions in reducing mother-to-child transmission of HIV

\begin{tabular}{|c|c|c|c|c|}
\hline Study, site, date & $\begin{array}{l}\text { Sample } \\
\text { size }\end{array}$ & Intervention & Efficacy & Breast fed \\
\hline $\begin{array}{l}\text { Biggar et al., } \\
\text { Malawi, } 1996\end{array}$ & 982 & $\begin{array}{l}\text { Mother: manual cleansing of birth canal with } \\
\text { chlorhexidine prior to delivery } \\
\text { Neonate: washing after birth with chlorhexidine }\end{array}$ & $\begin{array}{l}\text { No difference in percentage of infants HIV infected } \\
\text { at } 12 \text { wk ( } 27 \% \text { infected in intervention vs } 28 \% \text { in } \\
\text { placebo group) } \\
\text { Subgroup effect in those with } \mathrm{ROM}>4 \mathrm{~h}(\% \\
\text { reduction): } 36.5(95 \% \mathrm{Cl} 25.6,47.5) \mathrm{p}=0.02\end{array}$ & Yes \\
\hline $\begin{array}{l}\text { European Mode of } \\
\text { Delivery, }{ }^{[80]} \text { Europe, } \\
1999\end{array}$ & 370 & Elective cesarean section at $38 \mathrm{wk}$ gestation & $\begin{array}{l}\text { Percentage reduction by intent-to-treat, elective } \\
\text { cesarean section vs vaginal in multivariate analysis: } \\
80 \%(95 \% \mathrm{Cl} 40.0,90.0) \mathrm{p}<0.001\end{array}$ & No \\
\hline $\begin{array}{l}\text { Coutsoudis et al., }{ }^{[85]} \\
\text { South Africa, } 1999\end{array}$ & 728 & $\begin{array}{l}\text { Daily supplement of } 5000 \mathrm{IU} \text { retinyl palmitate and } \\
30 \mathrm{mg} \beta \text {-carotene from } 28 \text { to } 32 \mathrm{wk} .200 \text { 000IU } \\
\text { megadose of retinyl palmitate at delivery }\end{array}$ & $\begin{array}{l}\text { Percentage of infants HIV infected by 3mo: } \\
\text { Vitamin A: } 20.3 \%(95 \% \mathrm{Cl} 15.7,24.9) \\
\text { Placebo: } 22.3 \%(95 \% \mathrm{Cl} 17.5,27.1)\end{array}$ & Yes \\
\hline $\begin{array}{l}\text { Fawzi et al. }{ }^{[86]} \\
\text { Tanzania, } 2000\end{array}$ & 962 & $\begin{array}{l}\text { Factorial design: } \\
\text { Factor 1: Vitamin A ( } 30 \mathrm{mg} \beta \text {-carotene plus } 5000 \mathrm{IU} \\
\text { preformed vitamin A, oral vitamin A delivery) } \\
\text { Factor } 2 \text { : Multivitamins excluding vitamin A ( } 20 \mathrm{mg} \\
\text { B1, } 20 \mathrm{mg} \text { B2, } 25 \mathrm{mg} \mathrm{B} 6,100 \mathrm{mg} \text { niacin, } 50 \mu \mathrm{g} \mathrm{B} 12 \text {, } \\
500 \mathrm{mg} \mathrm{C}, 30 \mathrm{mg} \text { vitamin } \mathrm{E} \text { and } 0.8 \mathrm{mg} \text { folic acid) }\end{array}$ & $\begin{array}{l}\text { Risk of HIV at } 6 \text { wk among infants HIV-negative } \\
\text { at birth in experimental groups compared with } \\
\text { placebo } \\
\text { Vitamin A: RR }=1.04(95 \% \mathrm{Cl} 0.65,1.66) \\
\text { Multivitamin: } \mathrm{RR}=1.30(95 \% \mathrm{Cl} 0.80,2.09)\end{array}$ & Yes \\
\hline $\begin{array}{l}\text { Gaillard et al., }{ }^{[87]} \\
\text { Kenya, } 2001\end{array}$ & 606 & $\begin{array}{l}\text { Mother: Flushing of cervical area with } 60 \mathrm{ml} \\
\text { chlorhexidine solution during labor every } 3 \mathrm{~h} \text { until } \\
\text { delivery }\end{array}$ & $\begin{array}{l}\text { Risk of infant HIV infection by } 14 \mathrm{wk} \text { : OR of } \\
\text { intervention vs placebo } 0.9(95 \% \mathrm{Cl} 0.6,1.4)\end{array}$ & Yes \\
\hline
\end{tabular}

$\mathbf{C I}=$ confidence intervals; $\mathbf{m o}=$ months; $\mathbf{O R}=$ odds ratio; $\mathbf{R O M}=$ duration of membrane rupture prior to delivery; $\mathbf{R R}=$ relative risk; $\mathbf{w k}=$ weeks. 
be between 0 and $2 \%$ in some populations if both interventions are implemented. ${ }^{[15,83]}$

Despite these encouraging findings, the benefit associated with cesarean sections in preventing vertical HIV transmission should be balanced against the potential surgical risks to the mother. ${ }^{[88,89]}$ Postoperative morbidity and mortality are greater among immunocompromised people and are also considerably higher in developing countries. Significantly increased postdelivery complications have been observed among HIV-infected women undergoing cesarean compared with non-cesarean delivery. ${ }^{[82,88,89]}$ Under current conditions, elective cesarean section is not a feasible preventive strategy against HIV transmission in developing countries. In developed countries, the added benefits of elective cesarean section should be considered in relation to the apparently high efficacy of combination therapy with antiretroviral drugs. Although not without side effects and toxicities, combination therapy may be safer than surgical delivery.

A simpler and safer obstetric intervention proposed to prevent intrapartum HIV transmission is the use of vaginal lavage, which entails washing the birth canal with an antiseptic during labor. An advantage of vaginal lavage is that it can safely be conducted on all women giving birth, which is particularly beneficial in settings with low levels of HIV testing. The potential efficacy of vaginal lavage to prevent HIV transmission is based on the assumption that antiseptic washes can successfully reduce neonatal exposure to maternal blood and genital secretions in the birth canal. Vaginal lavage may also be effective in preventing ascending HIV infection, since it has been shown to reduce vertical transmission of other infections, such as group B streptococci, which are known to infect neonates by ascending through the birth canal prior to delivery. ${ }^{[90]}$

Unfortunately, data now available from two separate clinical trials, one carried out in Malawi and the other in Kenya, do not support the use of chlorhexidine vaginal lavage as an effective means of preventing perinatal HIV transmission (table II). ${ }^{[84,87]}$ In the Malawian trial, vaginal lavage had no effect on HIV transmission rates overall, but was associated with a reduction in transmission among women who experienced ruptured membranes for more than 4 hours prior to delivery ${ }^{\left[{ }^{[8]}\right.}$ however, this subgroup finding was not replicated in the Kenyan trial. ${ }^{[87]}$ Factors that may account for the null effects include the type or concentration of solution used, the effectiveness of the solution in reducing viral exposures, or an overestimation of the importance of birth canal exposure in HIV transmission. Importantly, reductions were observed in severe maternal and neonatal morbidity and in neonatal mortality due to infectious causes, ${ }^{[91]}$ suggesting that chlorhexidine vaginal lavage may have more general health benefits in pop- ulations in developing countries, despite its apparent lack of effect in reducing mother-to-child HIV transmission.

\subsection{Vitamin A and Other Micronutrients}

Interest in vitamin $\mathrm{A}$ as a potential preventive measure against mother-to-child HIV transmission was piqued by a study in Malawi that observed a strong dose-response relationship between serum levels of retinol in HIV-infected women and the risk of HIV transmission, even after adjusting for other factors associated with transmission including maternal CD4+ T lymphocyte counts, clinical symptoms, and body mass index. ${ }^{\left[{ }^{[2]}\right.}$ Based on these data, as well as on studies of the association between serum retinol and disease progression among HIV-infected adults, ${ }^{[93]}$ and on studies showing some benefits of vitamin A supplementation in reducing morbidity in HIV-infected children, ${ }^{\left[{ }^{[4]}\right.}$ clinical trials were set up to test whether supplementation of pregnant HIV-infected women with vitamin A could reduce the risk of mother-to-child HIV transmission. The hypothesized mechanisms underlying putative vitamin A benefit were stimulation of the immune system and/or maintenance of the integrity of mucosal surfaces.

The results of two trials, one conducted in South Africa and one in Tanzania, have now been published: neither trial reported significant reductions in HIV transmission among women receiving vitamin A rather than placebo (table II). ${ }^{[85,86]}$ The contradictory findings between clinical trials and the nonexperimental observational study in Malawi may be explained as follows: low serum vitamin A may only be a marker of advanced disease (not reflected in CD4 counts) or other nutritional deficiencies, which in turn are the true factors influencing HIV transmission. Although vitamin supplementation has not been shown to reduce rates of HIV transmission, findings from the South African and Tanzanian trials suggested other benefits of micronutrient supplementation. For example, in the Tanzanian trial, which also included a multivitamin arm, significant benefits were observed for multivitamin supplementation on maternal CD4+ T lymphocyte counts and on adverse pregnancy outcomes, including perinatal mortality. ${ }^{[95]}$ Although apparently without demonstrable benefit regarding mother-to-child HIV transmission, nutritional interventions, similarly to vaginal lavage, may have other health benefits among populations in developing countries with a high seroprevalence of HIV.

\subsection{Exclusive Breast Feeding and Early Cessation of Breast Feeding}

Assuming the successful implementation of programs to ensure access of HIV-infected women to short-course antiretroviral 
drug interventions, postnatal HIV transmission will become the predominant route of mother-to-child HIV transmission in developing countries. In developed countries, it is universally recommended that HIV-infected women formula feed their infants to avoid any risk of HIV infection through breast feeding; however, in resource-poor areas in developing countries, formula feeding is not a reasonable option for many women, primarily because formula-fed infants experience higher rates of mortality from diarrheal and respiratory disease than breast-fed infants. ${ }^{[96-102]} \mathrm{An}$ important issue, then, is to establish infant feeding recommendations for HIV-infected women in resource-poor settings that balance the risk of postnatal HIV transmission against the risk of nonHIV infant mortality.

To address the question of competing risks, several researchers have used mathematical modeling to quantify adverse outcomes (mortality or HIV infection) associated with infant-feeding options under various conditions. ${ }^{[103-108]}$ Results of these models have shown that optimal strategies, in terms of reducing the overall number of adverse events, are highly sensitive to background infant mortality rates and to the expected risks associated with avoidance of breast feeding. ${ }^{[105,107,108]}$ The latter, particularly, is seldom known with any precision. In populations with high background infant mortality rates, even small to moderately increased risks associated with an avoidance of breast feeding can wipe out gains achieved by avoiding breast feeding-associated HIV transmission. ${ }^{[105,107,108]}$ Another unequivocal finding from mathematical models is that shifts away from breast feeding, if not confined to HIV-infected women, always have the worst outcome. ${ }^{\text {103-108] }}$ This underscores the need to protect and support breast feeding in uninfected women and also the importance of HIV testing. Unfortunately, tailoring infant-feeding advice specifically to a woman's sero-status may contribute to stigma and unintended disclosure of HIV status.

A promising new line of research has recently been broached with findings from a nonexperimental, prospective study carried out in Durban, South Africa, which demonstrated that exclusive breast feeding was associated with a significant reduction in postnatal transmission of HIV ${ }^{[40]}$ Among infants who were HIV RNA negative by PCR at birth, $8 \%$ had detectable HIV RNA in peripheral blood by 3 months of age, if exclusively breast fed to this age. This proportion was similar to that observed in never breast-fed infants (13\%) and hence presumably attributable to intrapartum transmission. In contrast, a higher proportion of infants negative by PCR at birth (20\%) had HIV RNA detected by 3 months of age if breast fed partially or predominantly (i.e. other foods and drinks supplemented breast feeding). This proportion presumably included intrapartum plus postnatal transmission. ${ }^{[40]}$
Longer follow-up of these infants supported the protective benefits of exclusive breast feeding throughout the period that breast feeding continued to be exclusive (the maximum duration of exclusive breast feeding was 6 months). ${ }^{[109]}$ Further studies are needed to exclude the possibility that self-selection and other methodologic issues account for the apparent protective effect of exclusive breast feeding found in this observational study; however, if supported with further evidence, exclusive breast feeding may represent an effective way to reduce mother-to-child HIV transmission, while maintaining the benefits of breast-milk nutrition for infants in resource-poor settings. Exclusive breast feeding is, unequivocally, the healthiest option for infants during their first 6 months of life, in the absence of HIV infection.

Exclusive breast feeding is a novel concept for reducing the risk of HIV transmission; however, its protective effects against morbidity associated with gastrointestinal and respiratory disease are well established, and several biological mechanisms have been investigated to account for these effects. ${ }^{[110]}$ The relevance of these mechanisms to reduced HIV transmission is as yet unknown, but they provide biological plausibility for the observed association. For example, exclusive breast feeding exposes the child to fewer bacterial contaminants and to a restricted range of food antigens. This may reduce immune activation in the gastrointestinal tract. Exclusive breast feeding also facilitates maturation of the infant's gut and may assist in maintaining the integrity of the intestinal mucosal barrier. ${ }^{[110]}$

In the Durban study, after 6 months of age, new infections were detected among previously exclusively breast-fed infants, if breast feeding continued supplemented with other foods and liquids. ${ }^{[109]}$ One way to avoid such late postnatal infections, after breast feeding can no longer be exclusive, is abrupt cessation of all breast feeding. Early cessation of breast feeding has been floated as an option to reduce postnatal HIV transmission but it has not yet garnered sufficient enthusiasm to spur an evaluation of its capacity to reduce mother-to-child HIV transmission. Although there are continuing benefits of longer duration of breast feeding ( $>6$ months) on infectious disease morbidity and mortality, on child cognitive development, and on extending postpartum amenorrhea, protection accorded by breast feeding from severe and life-threatening conditions is greatest in the first few months of life. ${ }^{[111-113]}$ In part, the lack of enthusiasm for early cessation of breast feeding may be because, on its own, it provides no means to reduce early postnatal HIV transmission. If, however, the protective benefits of exclusive breast feeding on postnatal transmission during the first few months of life are supported by further studies, short exclusive breast feeding may be the optimal infant feeding practice. Empiric testing of the safety and efficacy of 
the concept is of course essential. A concern was raised that breast feeding may have a detrimental effect on the health of HIV-infected mothers. ${ }^{[114]}$ This was not confirmed in another study; ${ }^{[115]}$ however, it is important that studies of interventions to reduce HIV transmission to the infant also include careful evaluation of the effect of these interventions on maternal health.

The practicality of achieving exclusive breast feeding among a large proportion of women should not be underestimated. Many barriers to exclusive breast feeding outside the HIV context have been identified, including cultural traditions, work outside the home, maternal health, and perceptions of insufficient milk production. ${ }^{[110]}$ HIV-infected women may be more receptive to modification of infant-feeding practices (given the emotional salience of HIV infection), but additional social, psychological and material barriers may reduce the impact of educational interventions. Food insecurity may contribute as a major impediment to shortening the duration of breast feeding, since in many developing countries, breast feeding continues to provide many children older than 6 months with substantial proportions of their nutrition. Independent of HIV prevention, several studies have demonstrated that it is possible to achieve significant improvements in the uptake and duration of exclusive breast feeding with modest educational interventions. ${ }^{[116-118]}$

\section{Conclusions}

Several interventions have been shown to be beneficial in reducing mother-to-child HIV transmission in utero, intrapartum and postnatally. Establishing high-quality programs to implement these effective interventions is now the challenge for years to come.

Prevention of mother-to-child HIV infection also cannot be separated from efforts to prevent HIV infection in adults. Prevention of HIV infection in the mothers and fathers of future generations remains the best means of preventing HIV infection in children.

\section{Acknowledgements}

This work was supported in part by grants from the National Institutes of Health (HD36177 and HD39611).

\section{References}

1. Kuhn L, Stein ZA. Mother-to-infant HIV transmission: timing, risk factors and prevention. Paediatr Perinat Epidemiol 1995; 9: 1-29

2. Mofenson LM. Can perinatal HIV infection be eliminated in the United States? JAMA 1999; 282: 577-9

3. De Cock KM, Fowler MG, Mercier E, et al. Prevention of mother-to-child HIV transmission in resource-poor countries: translating research into policy and practice. JAMA 2000; 283: 1175-82
4. Joint United Nations Programme on HIV/AIDS. UNAIDS [online]. Available from URL: http://www.unaids.org [Accessed $19 \mathrm{Feb} 2002]$

5. Newell M-L. Mechanisms and timing of mother-to-child transmission of HIV-1. AIDS 1998; 12: 831-7

6. Kuhn L, Steketee RW, Weedon J, et al. Distinct risk factors for intrauterine and intrapartum human immunodeficiency virus transmission and consequences for disease progression in infected children. J Infect Dis 1999; 179: 52-8

7. Dunn DT, Brandt CD, Krivine A, et al. The sensitivity of HIV-1 DNA polymerase chain reaction in the neonatal period and the relative contributions of intrauterine and intra-partum transmission. AIDS 1995; 9: F7-11

8. Chouquet C, Burgard M, Richardson S, et al. Timing of mother-to-child HIV-1 transmission and diagnosis of infection based on polymerase chain reaction in the neonatal period by a non-parametric method. AIDS 1997; 11: 1183-99

9. Kalish LA, Pitt J, Lew J, et al. Defining the time of fetal or perinatal acquisition of human immunodeficiency virus type 1 infection on the basis of age at first positive culture. J Infect Dis 1997; 175: 712-5

10. Kuhn L, Abrams EJ, Chinchilla M, et al. Sensitivity of HIV-1 DNA polymerase chain reaction in the neonatal period. AIDS 1996; 10: 1181-2

11. Bryson YJ, Luzuriaga K, Sullivan JL, et al. Proposed definitions for in utero versus intrapartum transmission of HIV-1. N Engl J Med 1992; 327: 1246-7

12. Goedert JJ, Duliege AM, Amos CI, et al. High risk of HIV-1 infection for firstborn twins. Lancet 1991; 338: 1471-5

13. Duliege AM, Amos CI, Felton S, et al. Birth order, delivery route, and concordance in the transmission of human immunodeficiency virus type 1 from mothers to twins. J Pediatr 1995; 126: 625-32

14. Minkoff H, Burns DN, Landesman S, et al. The relationship of the duration of ruptured membranes to vertical transmission of human immunodeficiency virus. Am J Obstet Gynecol 1995; 173: 585-9

15. International Perinatal HIV Group. The mode of delivery and the risk of vertical transmission of human immunodeficiency virus type 1: a meta-analysis of 15 prospective cohort studies. N Engl J Med 1999; 340: 977-87

16. Mofenson LM. A critical review of studies evaluating the relationship of mode of delivery to perinatal transmission of human immunodeficiency virus. Pediatr Infect Dis J 1995; 14: 169-76

17. De Andreis C, Simoni G, Rossella F, et al. HIV-1 proviral DNA polymerase chain reaction detection in chorionic villi after exclusion of maternal contamination by variable number of tandem repeats analysis. AIDS 1996; 10: 711-5

18. Menu E, Mbopi-Keou FX, Lagaye S, et al. Selection of maternal human immunodeficiency virus type 1 variants in human placenta. European Network for In Utero Transmission of HIV-1. J Infect Dis 1999; 179: 44-51

19. Amirhessami-Aghili N, Spector SA. Human immunodeficiency virus type 1 infection of human placenta: potential route for fetal infection. J Virol 1991; 65: 2231-6

20. Kesson AM, Fear WR, Kazazi F, et al. Human immunodeficiency virus type 1 infection of human placental macrophages in vitro. J Infect Dis 1993; 168: $571-9$

21. Tscherning-Casper C, Papadogiannakis N, Anvret M, et al. The trophoblastic epithelial barrier is not infected in full-term placentae of human immunodeficiency virus-seropositive mothers undergoing antiretroviral therapy. J Virol 1999; 73: 9673-8

22. Mano H, Chermann JC. Fetal human immunodeficiency virus type 1 infection of different organs in the second trimester. AIDS Res Hum Retroviruses 1991; 7 : 83-8

23. Courgnaud V, Laure F, Brossard A, et al. Frequent and early in utero HIV-1 infection. AIDS Res Hum Retroviruses 1991; 7: 337-41

24. Soeiro R, Rubinstein A, Rashbaum WK, et al. Maternofetal transmission of AIDS: frequency of human immunodeficiency virus type 1 nucleic acid sequences in human fetal DNA. J Infect Dis 1992; 166: 699-703

25. Langston C, Lewis DE, Hammill HA, et al. Excess intrauterine fetal demise associated with maternal human immunodeficiency virus infection. J Infect Dis 1995; 172: 1451-60 
26. Dunn DT, Newell ML, Ades AE, et al. Risk of human immunodeficiency virus type 1 transmission through breastfeeding. Lancet 1992; 340: 585-8

27. Nduati R, John G, Mbori-Ngacha D, et al. Effect of breastfeeding and formula feeding on transmission of HIV-1: A randomized clinical trial. JAMA 2000; 283: 1167-74

28. Miotti PG, Taha TE, Kumwenda NI, et al. HIV transmission through breast feeding: a study in Malawi. JAMA 1999; 282: 744-9

29. Dunn D, Tess BH, Rodrigues LC, et al. Mother-to-child transmission of HIV: implications of variation in maternal infectivity. AIDS 1998; 12: 2211-6

30. Bertolli J, St Louis ME, Simonds RJ, et al. Estimating the timing of mother-to-child transmission of human immunodeficiency virus in a breast-feeding population in Kinshasa, Zaire. J Infect Dis 1996; 174: 722-6

31. Bulterys M, Chao A, Dushimimana A, et al. HIV-1 seroconversion after 20 months of age in a cohort of breastfed children born to HIV-1 infected women in Rwanda. AIDS 1995; 9: 93-4

32. Lepage $P$, Van de Perre $P$, Simonon A, et al. Transient seroreversion in children born to human immunodeficiency virus 1-infected mothers. Pediatr Infect Dis J 1992; 11: $892-4$

33. Datta P, Embree JE, Kreiss JK, et al. Mother-to-child transmission of human immunodeficiency virus type 1: Report from the Nairobi study. J Infect Dis 1994; 170: 1134-40

34. Ekpini ER, Wiktor SZ, Satten GA, et al. Late postnatal mother-to-child transmission of HIV-1 in Abidjan, Cote d'Ivoire. Lancet 1997; 349: 1054-9

35. Leroy V, Newell ML, Dabis F, et al. International multicentre pooled analysis of late postnatal mother-to-child transmission of HIV-1 infection. Lancet 1998; 352: 597-600

36. Cohen RJ, Brown KH, Canahuati J, et al. Effects of age of introduction of complementary foods on infant breast milk intake, total energy intake, and growth: a randomised intervention study in Honduras. Lancet 1994; 344: 288-93

37. Brown KH, Black RE, Lopez de Romana G, et al. Infant-feeding practices and their relationship with diarrheal and other diseases in Huascar (Lima) Peru. Pediatrics 1989; 83: 31-40

38. Black R, Lopez de Romana G, Brown KH, et al. Incidence and etiology of infantile diarrhea and major routes of transmission in Huascar, Peru. Am J Epidemiol 1989; 129: 785-99

39. Cesar JA, Victora CG, Barros FC, et al. Impact of breast feeding on admission for pneumonia during the postnatal period in Brazil: nested case-control study. BMJ 1999; 318: 1316-20

40. Coutsoudis A, Pillay K, Spooner E, et al. Influence of infant feeding patterns on early mother-to-child transmission of HIV-1 in Durban, South Africa. Lancet 1999; 354: 471-6

41. Van de Perre P, Simonon A, Msellati P, et al. Postnatal transmission of human immunodeficiency virus type 1 from mother to infant. A prospective cohort study in Kigali, Rwanda. N Engl J Med 1991; 325: 593-8

42. Connor EM, Sperling RS, Gelber R, et al. Reduction of maternal-infant transmission of human immunodeficiency virus type 1 with zidovudine treatment. N Engl J Med 1994; 331: 1173-80

43. Cooper ER, Nugent RP, Diaz C, et al. After AIDS Clinical Trial 076: the changing pattern of zidovudine use during pregnancy, and the subsequent reduction in the vertical transmission of human immunodeficiency virus in a cohort of infected women and their infants. J Infect Dis 1996; 174: 1207-11

44. Boyer PJ, Dillon M, Navaie M, et al. Factors predictive of maternal-fetal transmission of HIV-1. Preliminary analysis of zidovudine given during pregnancy and/or delivery. JAMA 1994; 271: 1925-30

45. Matheson PB, Abrams EJ, Thomas PA, et al. Efficacy of antenatal zidovudine in reducing perinatal transmission of human immunodeficiency virus type 1 . J Infect Dis 1995; 172: 353-8

46. Frenkel LM, Cowles MK, Shapiro DE, et al. Analysis of the maternal components of the AIDS clinical trial group 076 zidovudine regimen in the prevention of mother-to- infant transmission of human immunodeficiency virus type 1 . J Infect Dis 1997; 175: 971-4
47. Simonds RJ, Steketee R, Nesheim S, et al. Impact of zidovudine use on risk and risk factors for perinatal transmission of human immunodeficiency virus. AIDS 1998; 12: 301-8

48. Wade NA, Birkhead GS, Warren BL, et al. Abbreviated regimens of zidovudine prophylaxis and perinatal transmission of the human immunodeficiency virus. N Engl J Med 1998; 339: 1409-14

49. Fiscus SA, Adimora AA, Schoenbach VJ, et al. Perinatal HIV infection and the effect of zidovudine therapy on transmission in rural and urban counties. JAMA 1996; 275: 1483-8

50. Lindegren ML, Byers RHJ, Thomas $\mathrm{P}$, et al. Trends in perinatal transmission of HIV/AIDS in the United States. JAMA 1999; 282: 531-8

51. Wortley PM, Fleming PL, Lindegren ML, et al. Using HIV/AIDS surveillance to monitor public health efforts to reduce perinatal transmission of HIV. J Acquir Immune Defic Syndr 1996; 11: 205-6

52. Centers for Disease Control and Prevention. Success in implementing public health service guidelines to reduce perinatal transmission of HIV - Louisiana, Michigan, New Jersey, and South Carolina, 1993, 1995, and 1996. MMWR Morb Mortal Wkly Rep 1998; 47: 688-91

53. Bayer R. The debate over maternal-fetal HIV transmission prevention trials in Africa, Asia, and the Caribbean: racist exploitation or exploitation of racism? Am J Public Health 1998; 88: 567-70

54. Wiktor SZ, Ekpini ER, Karon JM, et al. Short-course oral zidovudine for prevention of mother-to-child transmission of HIV-1 in Abidjan, Côte d'Ivoire: a randomized trial. Lancet 1999; 353: 781-5

55. Dabis F, Msellati A, Meda N, et al. 6-Month efficacy, tolerance, and acceptability of a short regimen of oral zidovudine to reduce vertical transmission of HIV in breast fed children in Côte d'Ivoire and Burkina Faso: a double-blind placebocontrolled multicentre trial. Lancet 1999; 353: 786-92

56. Shaffer N, Chuachoowong R, Mock PA, et al. Short-course zidovudine for perinatal HIV-1 transmission in Bangkok, Thailand: a randomized controlled trial. Lancet 1999; 353: 773-80

57. Saba J. Results of the PETRA intervention trial to prevent perinatal transmission in sub-Saharan Africa. Proceedings of the 6th Conference on Retroviruses and Opportunistic Infections; 1999 Feb 4-Jan 31; Chicago (IL).

58. Guay LA, Musoke P, Fleming $\mathrm{T}$, et al. Intrapartum and neonatal single-dose nevirapine compared with zidovudine for prevention of mother-to-child transmission of HIV-1 in Kampala, Uganda: HIVNET 012 randomised trial. Lancet 1999; 354: 795-802

59. DITRAME ANRS 049 Study Group. 15-Month efficacy of maternal oral zidovudine to decrease vertical transmission of HIV-1 in breastfed African children. Lancet 1999; 354: 2050-1

60. Lallemant M, Jourdain G, Le Coeur S, et al. A trial of shortened zidovudine regimens to prevent mother-to-child transmission of human immunodeficiency virus type 1. Perinatal HIV Prevention Trial (Thailand) Investigators. N Engl J Med 2000; 343: 982-91

61. Cao Y, Krogstad P, Korber BT, et al. Maternal HIV-1 viral load and vertical transmission of infection: the Ariel Project for the prevention of HIV transmission from mother to infant. Nature Med 1997; 3: 549-52

62. Garcia PM, Kalish LA, Pitt J, et al. Maternal levels of plasma human immunodeficiency virus type 1 RNA and the risk of perinatal transmission. Women and Infants Transmission Study Group. N Engl J Med 1999; 341: 394-402

63. Thea DM, Steketee RW, Pliner V, et al. The effect of maternal viral load on the risk of perinatal transmission of HIV-1. AIDS 1997; 11: 437-44

64. Sperling RS, Shapiro DE, Coombs RW, et al. Maternal viral load, zidovudine treatment, and the risk of transmission of human immunodeficiency virus type 1 from mother to infant. N Engl J Med 1996; 335: 1621-9

65. Anonymous. Case-control study of HIV seroconversion in health-care workers after percutaneous exposure to HIV-infected blood: France, United Kingdom, and United States, January 1988-August 1994. MMWR Morb Mortal Wkly Rep 1995; 44: 929-33 
66. McGowan JP, Crane M, Wiznia AA, et al. Combination antiretroviral therapy in human immunodeficiency virus-infected pregnant women. Obstet Gynecol 1999; 94: 641-6

67. Cooper ER, Charurat M, Burns DN, et al. Trends in antiretroviral therapy and mother-infant transmission of HIV. The Women and Infants Transmission Study Group. J Acquir Immune Defic Syndr 2000; 24: 45-7

68. Sperling RS, Shapiro DE, McSherry GD, et al. Safety of the maternal-infant zidovudine regimen utilized in the Pediatric AIDS Clinical Trial Group 076 Study. AIDS 1998; 12: 1805-13

69. Chotpitayasunondh T, Vanprapar N, Simonds RJ, et al. Safety of late in utero exposure to zidovudine in infants born to human immunodeficiency virusinfected mothers: Bangkok. Pediatrics 2000; 107 (1): 1-6

70. Blanche S, Tardieu M, Rustin P, et al. Persistent mitochondrial dysfunction and perinatal exposure to antiretroviral nucleoside analogues. Lancet 1999; 354: 1084-9

71. Mandelbrot L, Landreau-Mascaro A, Rekacewicz C, et al. Lamivudine-zidovudine combination for prevention of maternal-infant transmission of HIV-1. JAMA 2001; 285: 2083-93

72. The Perinatal Safety Review Working Group. Nucleoside exposure in the children of HIV-infected women receiving antiretroviral drugs: absence of clear evidence for mitochondrial disease in children who died before 5 years of age in five United States cohorts. J Acquir Immune Defic Syndr 2000; 25: 261-8

73. Olivero OA, Shearer GM, Chougnet CA, et al. Incorporation of zidovudine into leukocyte DNA from HIV-1-positive adults and pregnant women, and cord blood from infants exposed in utero. AIDS 1999; 13: 919-25

74. Colgrove RC, Pitt J, Chung PH, et al. Selective vertical transmission of HIV-1 antiretroviral resistance mutations. AIDS 1998; 12: 2281-8

75. Eastman PS, Shapiro DE, Coombs RW, et al. Maternal viral genotypic zidovudine resistance and infrequent failure of zidovudine therapy to prevent perinatal transmission of human immunodeficiency virus type 1 in Pediatric AIDS Clinical Trial Group Protocol 076. J Infect Dis 1998; 177: 557-64

76. Frenkel LM, Wagner LE, Demeter LM, et al. Effects of zidovudine use during pregnancy on resistance and vertical transmission of human immunodeficiency virus type 1. Clin Infect Dis 1995; 20: 1321-6

77. Welles SL, Pitt J, Colgrove R, et al. HIV-1 genotypic zidovudine drug resistance and the risk of maternal-infant transmission in the women and infants transmission study. AIDS 2000; 14: 263-71

78. Kully C, Yerly S, Erb P, et al. Codon 215 mutations in human immunodeficiency virus-infected pregnant women. J Infect Dis 1999; 179: 705-8

79. Jackson JB, Becker-Pergola G, Guay LA, et al. Identification of the K103N resistance mutation in Ugandan women receiving nevirapine to prevent HIV-1 vertical transmission. AIDS 2000; 14: F111-5

80. European Collaborative Study. Caesarean section and risk of vertical transmission of HIV-1 infection. Lancet 1994; 343: 1464-7

81. Mandelbrot L, Mayaux MJ, Bongain A, et al. Obstetric factors and mother-to-child transmission of human immunodeficiency virus type 1: the French perinatal cohorts. Am J Obstet Gynecol 1996; 175: 661-7

82. European Mode of Delivery Collaboration. Elective caesarean section versus vaginal delivery in prevention of vertical HIV-1 transmission: a randomised clinical trial. Lancet 1999; 353: 1035-9

83. Kind C, Rudin C, Siegrist CA, et al. Prevention of vertical HIV transmission: additive protective effect of elective cesarean section and zidovudine prophylaxis. AIDS 1998; 12: 205-10

84. Biggar RJ, Miotti PG, Taha TE, et al. Perinatal intervention trial in Africa: effect of a birth canal cleansing intervention to prevent HIV transmission. Lancet 1996; 347: 1647-50

85. Coutsoudis A, Pillay K, Spooner E, et al. Randomised trial testing effect of vitamin A supplementation on pregnancy outcomes and early mother-to-child transmission of HIV-1 in Durban, South Africa. AIDS 1999; 13: 1517-24

86. Fawzi WW, Msamanga G, Hunter D, et al. Randomized trial of vitamin supplements in relation to vertical transmission of HIV-1 in Tanzania. J Acquir Immune Defic Syndr 2000; 23: 246-54
87. Gaillard P, Mwanyumba F, Verhofstede C, et al. Vaginal lavage with chlorhexidine during labour to reduce mother-to-child HIV transmission: clinical trial in Mombassa, Kenya. AIDS 2001; 15: 389-96

88. Semprini AE, Castagna C, Ravizza M, et al. The incidence of complications after caesarean section in 156 HIV-positive women. AIDS 1995; 9: 913-7

89. Maiques-Montesinos V, Cervera-Sanchez J, Bellver-Pradas J, et al. Post-cesarean section morbidity in HIV-positive women. Acta Obstet Gynecol Scand 1999; 78: 789-92

90. Burman L, Christensen P, Christensen K, et al. Prevention of excess neonatal morbidity associated with group B streptococci by vaginal chlorhexidine disinfection during labor. Lancet 1992; 340: 65-9

91. Taha TE, Biggar RJ, Broadhead RL, et al. Effect of cleansing the birth canal with antiseptic solution on maternal and newborn morbidity and mortality in Malawi: clinical trial. BMJ 1997; 315: 216-9

92. Semba RD, Miotti PG, Chiphangwi JD, et al. Maternal vitamin A deficiency and mother-to-child transmission of HIV-1. Lancet 1994; 343: 1593-7

93. Semba RD, Caiaffa WT, Graham NMH, et al. Vitamin A deficiency and wasting as predictors of mortality in human immunodeficiency virus-infected injection drug users. J Infect Dis 1995; 171: 1196-202

94. Coutsoudis A, Bobat RA, Coovadia HM, et al. The effects of vitamin A supplementation on the morbidity of children born to HIV-infected women. Am J Public Health 1995; 85: 1076-81

95. Fawzi WW, Msamanga GI, Spiegelman D, et al. Randomised trial of effects of vitamin supplements on pregnancy outcomes and T cell counts in HIV-1-infected women in Tanzania. Lancet 1998; 351: 1477-82

96. Nicoll A, Newell ML, Van Praag E, et al. Infant feeding policy and practice in the presence of HIV-1 infection. AIDS 1995; 9: 107-19

97. Habicht JP, DaVanzo J, Butz WP. Mother's milk and sewage: their interactive effects on infant mortality. Pediatrics 1988; 81: 456-61

98. Briend A, Wojtyniak B, Rowland MG. Breast feeding, nutritional state, and child survival in rural Bangladesh. BMJ 1988; 296: 879-82

99. Victora CG, Smith PG, Vaughan JP, et al. Evidence for protection by breast-feeding against infant deaths from infectious diseases in Brazil. Lancet 1987; II: 319-22

100. Plank SJ, Milanesi ML. Infant feeding and infant mortality in rural Chile. Bull World Health Organ 1973; 48: 203-10

101. Habicht JP, DaVanzo J, Butz WP. Does breastfeeding really save lives, or are apparent benefits due to biases? Am J Epidemiol 1986; 123: 279-90

102. Feachem RG, Koblinsky MA. Interventions for the control of diarrhoeal diseases among young children: promotion of breast-feeding. Bull World Health Organ 1984; 62: 271-91

103. Nicoll A, Killewo JZ, Mgone C. HIV and infant feeding practices: epidemiological implications for sub-Saharan African countries. AIDS 1990; 4: 661-5

104. Heymann SJ. Modeling the impact of breast-feeding by HIV-infected women on child survival. Am J Public Health 1990; 80: 1305-9

105. Hu DJ, Heyward WL, Byers Jr RH, et al. HIV infection and breast-feeding: policy implications through a decision analysis model. AIDS 1992; 6: 1505-13

106. Lederman SA. Estimating infant mortality from human immunodeficiency virus and other causes in breast-feeding and bottle-feeding populations. Pediatrics 1992; 89: 290-6

107. Del Fante P, Jenniskens F, Lush L, et al. HIV, breast-feeding and under-5 mortality: modelling the impact of policy decisions for or against breast-feeding. J Trop Med Hyg 1993; 96: 203-11

108. Kuhn L, Stein Z. Infant survival, HIV infection and feeding alternatives in less developed countries. Am J Public Health 1997; 87: 926-31

109. Coutsoudis A, Pillay K, Kuhn L, et al. Method of feeding and transmission of HIV-1 from mothers to children by 15 months of age: prospective cohort study from Durban, South Africa. AIDS 2001; 15: 379-87

110. Smith MM, Kuhn L. Exclusive breast-feeding: Does it have the potential to reduce breast-feeding transmission of HIV-1? Nutr Rev 2000; 58: 333-40

111. Cunningham AS, Jelliffe DB, Jelliffe EF. Breast-feeding and health in the 1980s: a global epidemiologic review. J Pediatr 1991; 118: 659-66 
112. Marquis GS, Habicht J-P, Lanata CF, et al. Breast milk or animal-product foods improve linear growth of Peruvian toddlers consuming marginal diets. Am J Clin Nutr 1997; 66: 1102-9

113. McNeilly AS. Lactation amenorrhea. Endocrinol Metab Clin North Am 1993; 22: 59-73

114. Nduati R, Richardson BA, John G, et al. Effect of breastfeeding on mortality among HIV-1 infected women: a randomised trial. Lancet 2001; 357: 1651-5

115. Coutsoudis A, Coovadia H, Pillay K, et al. Are HIV-infected women who breastfeed at increased risk of mortality? AIDS 2001; 15: 653-5

116. Morrow AL, Guerrero L, Shults J, et al. Efficacy of home-based peer counselling to promote exclusive breastfeeding: a randomised controlled trial. Lancet 1999; 353: $1226-31$
117. Haider R, Ashworth A, Kabir I, et al. Effect of community-based peer counsellors on exclusive breastfeeding practices in Dhaka, Bangladesh: a randomised controlled trial. Lancet 2000; 356: 1643-7

118. Kramer MS, Chalmers B, Hodnett E, et al. Promotion of Breastfeeding Intervention Trial (PROBIT): a randomized trial in the Republic of Belarus. JAMA 2001; 285: 413-20

Correspondence and offprints: Dr Louise Kuhn, Sergievsky Center, $630 \mathrm{~W}$ 168th Street, New York, NY 10032, USA.

E-mail: 1k24@columbia.edu 